\title{
Current Serum Lung Cancer Biomarkers
}

\author{
Jung-Mo Ahn and Je-Yoel Cho* \\ Department of Biochemistry, BK21 and Research Institute for Veterinary Science, College of Veterinary Medicine, Seoul National University, Seoul, Korea
}

\begin{abstract}
The development of proteomics technology over the past decade has advanced the identification and validation of new biomarkers. Clinical applications of serum biomarkers will benefit us by being cost-effective and non-invasive, as well as by allowing the simple detection of diseases. Numerous serum biomarkers for lung cancer have been identified and reported in publications. Despite extensive studies, cancer detection via a single marker remains difficult due to the low sensitivity, specificity and reproducibility of the identified lung cancer serum biomarkers. An optimal combination of multiple biomarkers, rather than a single biomarker, should be considered for the development of a lung cancer detection biomarker panel and should be validated with these combinatory markers. This review summarizes the lung cancer biomarkers that have been published within the last five years.
\end{abstract}

Keywords: Serum biomarkers; Lungs cancer; Adenocarcinoma

\section{Introduction}

Lung cancer is the most common cause of cancer mortality worldwide, accounting for $25 \%$ of all cancer deaths with an incidence rate of 1.2 million people per year [1]. The main risk factor of lung cancer is smoking; the risk of lung cancer is tenfold higher in smokers than in non-smokers [2]. Lung cancer can typically be grouped into two large categories: small-cell lung cancer (SCLC) and non-smallcell lung cancer (NSCLC), which account for 15\% and $85 \%$ of lung cancers, respectively. NSCLC consists of 3 major histological subtypes: Adenocarcinoma (ADC), Squamous Cell Lung Carcinoma (SQLC), and Large Cell Carcinoma (LCC). The five-year survival rate for lung cancer remains much lower than that of other cancers, at approximately $15 \%$ [3]. Survival rates remain low despite advancements of current lung cancer diagnostic methods such as X-rays and computed tomography (CT) scans. Furthermore, high cost, a high risk of radiation exposure, and poor sensitivity and specificity are problems with current screening techniques [4]. A better diagnostic measure for lung cancer that facilitates the early detection of the disease, therefore allowing for effective intervention, is necessary to lower lung cancer mortality rates. The discovery of cancer biomarkers, specific molecules that help to distinguish between normal and cancerous conditions, may potentially be used to develop a more effective diagnostic tool for lung cancer. Cancer biomarkers consist of either of genetic materials or proteins because cancer is a heterogeneous disease that reflects gene and protein changes within a cancer cell. However, proteins are the main functional units of biological processes. Almost all of the Food and Drug Administration (FDA)-approved cancer biomarkers are protein markers [5].

The recent advances in proteomics technologies, including mass spectrometry, protein labeling, protein array-based approaches, imaging, and protein bioinformatics, have enabled researchers to rapidly discover more biomarkers and to better understand their roles. Various putative biomarkers have been identified from blood samples, and these markers could be used to develop a non-invasive, costeffective method to identify individuals at high risk for lung cancer. Proteomics strategies provide powerful information toward bloodbased biomarker discovery (Figure 1). Cytokeratin-19 fragments (CYFRA 21-1), carcinoembryonic antigens (CEA), cancer antigen-125 (CA-125), and neuron-specific enolase (NSE) are among some of the lung cancer protein biomarkers that have been discovered to date. A multiple biomarker approach, rather than a single biomarker approach, is proposed for cancer detection due to the low sensitivity and specificity of individual biomarkers [2,6]. This review mainly discusses lung cancer serum biomarkers that have been published recently and the benefits of a multiple biomarker approach for lung cancer detection.

\section{Currently Available Biomarkers for Lung Cancer Detection via Blood Samples}

The following markers for use with blood samples are clinically available in some areas. They are currently used in a limited capacity as accessory blood biomarkers for lung cancers. Carcinoembryonic antigen (CEA) is an oncofetal protein not typically expressed in adult tissues. Functioning of the cell surface glycoprotein CEA involves cell adhesion and intracellular signaling. Some lung cancer cells are overexpressed by the de-repression of CEA-encoding genes. In lung cancers, the CEA levels in blood are elevated and are inversely correlated with the response to cancer therapy; therefore, this marker is used for the detection of cancer recurrence and the prediction of a poor survival rate [7]. CYFRA 21-1 is a fragment of cytokeratin 19 that is typically associated with epithelial cell cancers, including NSCLC, and is typically of the SQLC type. CYFRA 21-1 is correlated with disease response and the prognosis of cancer but cannot be used to identify cancer patients among patients with respiratory diseases. The sensitivity of CYFRA 21-1 for NSCLC ranges between 23 and 70\% [8,9]. Squamous cell carcinoma antigen is a structural cytoplasmic protein that is present at elevated levels in the blood of NSLC patients. It is also involved in terms of having metastatic potential. The sensitivity for NSCLC ranges from 15 to $55 \%[8,10]$. Neuron-specific enolase (NSE) is a glycolysis enzyme produced in neuronal cells and cells with neuroendocrine differentiation. In lung cancer, SCLC is of a neuroendocrine origin and

*Corresponding author: Je-Yoel Cho, DVM, PhD, Department of Veterinary Biochemistry, College of Veterinary Medicine, Seoul National University, Gwanak ro, Seoul 151-742, Korea, Tel: +82-2-880-1268; Fax: +82-2-886-1268; E-mail: jeycho@snu.ac.kr

Received January 25, 2013; Accepted February 18, 2013; Published February 20, 2013

Citation: Ahn JM, Cho JY (2013) Current Serum Lung Cancer Biomarkers. J Mol Biomark Diagn S4: 001. doi:10.4172/2155-9929.S4-001

Copyright: ( 2013 Ahn JM, et al. This is an open-access article distributed under the terms of the Creative Commons Attribution License, which permits unrestricted use, distribution, and reproduction in any medium, provided the original author and source are credited 


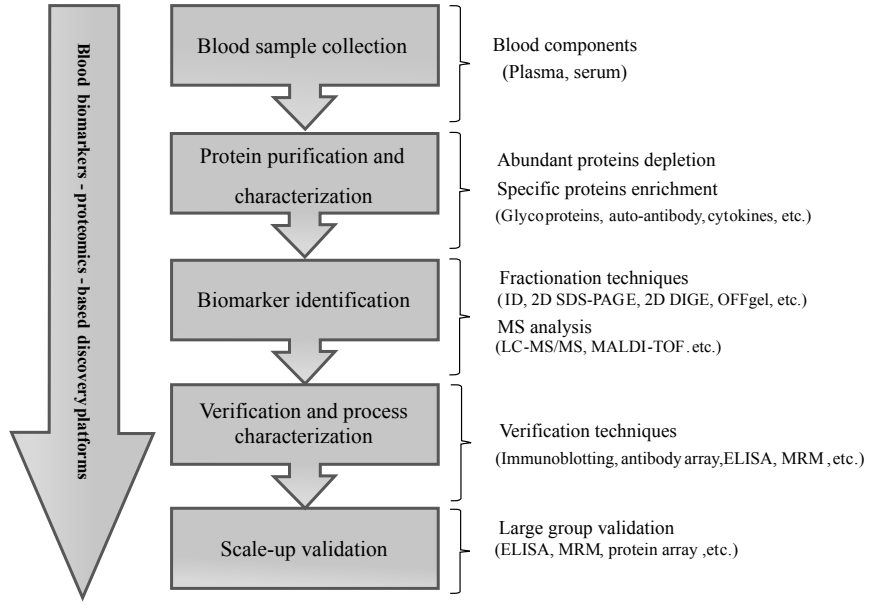

Figure 1: Proteomic platforms for blood biomarker discovery studies.

Blood is the most commonly used test sample in biomarker discovery studies. There are abundant proteins of all types in the blood; therefore, the depletion of abundant proteins and the enrichment of specific protein groups, such as glycoproteins, are needed before the identification steps. Protein separation is generally performed by gel electrophoresis and liquid chromatography in proteomic studies. Mass spectrometry is predominantly used for protein identification. LC-ESI-MS/MS and MALDI-TOF/MS are most commonly used for high throughput protein identification platforms. Verification steps for MS-based proteomics data involve immunoassays such as immunoblot, antibody arrays, and ELISAs. Recent developments incorporate a liquid chromatography-coupled mass spectrometry (LC-MS)-based verification system called multiple reaction monitoring (MRM)

is therefore found to be elevated in patients' blood. The sensitivity of NSE for detection of SCLC may be as high as 74\% [11]. Tumor M2pyruvate kinase (PKM2) is a dimeric form of the pyruvate kinase isoenzyme type $\mathrm{M} 2$ that is increased in various cancers. The sensitivity for lung cancer ranges from 50 to $71 \%$ and is especially high in ADC [8]. C-reactive protein (CRP) is an acute-phase protein, the levels of which rise in response to inflammatory conditions such as lung cancer. The blood CRP levels were increased in various cancers. However, the association between CRP and the risk of incident lung cancer was not stable in many published results. Recently, a CRP case-control study specifically conducted with respect to lung cancer concluded that high levels of CRP could be used as a prognosis biomarker of lung cancer and angiogenesis [12].

\section{Other Markers}

Proteomics is a powerful tool for identifying lung cancer biomarkers that can be tested in the blood. Previously, our group reported several potential lung cancer biomarkers, including plasma kallikrein (KLKB1) protein fragments, serum amyloid A (SAA), haptoglobin $\beta$ chain $[\mathrm{Hp}$ $\beta$ ], and complement component 9 (C9), using proteomics approaches. In this section, we will summarize recently reported lung cancer blood biomarkers, including those from our findings, which were discovered by proteomics technologies and were then validated in the patients' blood (Table 1).

\section{Plasma kallikrein (KLKB1)}

The KLKB1 enzyme cleaves Lys-Arg and Arg-Ser bonds in kininogen to release bradykinin and has functions related to blood coagulation, fibrinolysis, hemostasis, and inflammatory response [13]. We identified this protein in the glycoproteome-enriched sera of lung cancer patients using multilectin affinity chromatography combined with LC-MS/MS analysis. The serum levels of its fragmentation form, which is supposed to be glycosylated H4 domain (aa 292-375), were increased in lung cancer samples compared with normal control sera in a Western blot analysis [14].

\section{Serum Amyloid A (SAA)}

SAA proteins are a family of apolipoproteins associated with the high-density lipoprotein (HDL) complex that are secreted during the acute phase of inflammation. Three isoforms of SAA have been reported. The acute SAA (SAA1 and SAA2) levels are dominantly expressed in the liver during inflammation, whereas SAA3 is induced in various distinct tissues $[15,16]$. Our study identified SAA1/2 in the lung adenocarcinoma patients' sera by comparing the proteomes in healthy donor sera using LC-MS/MS analysis. High levels of SAA in the sera of lung cancer patients were detected by mass spectrometry, verified by Western blot, and quantified by ELISA. Expression of the SAA protein was also detected in lung cancer tissues by immunohistochemistry. The SAA levels were highly expressed in sera and tissues derived from lung cancers of various histological types (ADC, SQLC, and SCLC) in cancer patients compared with those of healthy controls. In using the $50 \mu \mathrm{g} / \mathrm{ml}$ cutoff criteria, the SAA ELISA showed between $50-70 \%$ sensitivity with $95 \%$ specificity. An in vitro experiment also demonstrated that lung cancer cells secreted SAA1 and SAA2, which stimulated infiltrating macrophages to induce matrix metallopeptidase 9 (MMP9), which has been suggested to help drive the metastasis of cancer cells [17]. A largescale, isotype-specific proteomics quantification method, multiple reaction monitoring (MRM), was also developed for SAA serum level validation. The MRM results also demonstrated significantly higher levels of SAA in the lung cancer patients' sera, which agrees with the ELISA results [18]. Our group also manufactured a chromatographybased rapid kit using developed dual monoclonal antibodies.

\section{Haptoglobin $\beta$ Chain (Hp $\beta)$}

Haptoglobin ( $\mathrm{Hp}$ ) is a free hemoglobin-binding glycoprotein that inhibits the oxidative stress of hemoglobin and assists in hemoglobin uptake by the hemoglobin scavenger receptor CD163. The molecular structures of $\mathrm{Hp}$ consist in tetramer of two $\alpha$ and two $\beta$ chains that are connected by a disulfide bridge [19]. High levels of blood $\mathrm{Hp}$ have been reported in various cancer types, such as breast cancer [20], ovarian cancer [21], pancreatic cancer [22], and bladder cancer [23]. In our study, the $\mathrm{Hp} \beta$ chain was indicated as a diagnostic marker for lung cancer of both NSCLC and SCLC types [24]. According to the proteomics analysis, $\mathrm{Hp} \beta$ chain region peptide levels were 3 fold higher in lung cancer patients' sera than in control subjects. The reason that the $\mathrm{Hp} \beta$ chain is a better diagnostic indicator may be due to its increased stability due to N-linked glycosylation at a site that is not found in the $\mathrm{Hp}$ a chain. The Western blot and ELISA results revealed significantly higher levels of the $\mathrm{Hp} \beta$ chain in lung cancer patients' sera and plasma compared with samples from other tumors that were associated with breast cancer, hepatocellular carcinoma and respiratory diseases of tuberculosis, idiopathic pulmonary fibrosis and bronchial asthma. In the ELISA analysis for lung adenocarcinoma and healthy control samples, when the cut-off was set at $2 \mu \mathrm{g} / \mathrm{ml}$, the AUC value was 0.822 and the specificity and sensitivity for the $\mathrm{Hp} \beta$ chain as a diagnostic marker were estimated at $63.2 \%$ and $82.6 \%$, respectively.

\section{Complement Component 9 (C9)}

Complement component 9 (C9) protein, a terminal constituent of the membrane attack complex (MAC-C5b, C6, C7, C8 and C9), plays a role in the immune response to cell death by forming pores in the plasma membrane of target cells [25]. C9 is a glycoprotein that has two 


\begin{tabular}{|c|c|c|c|c|c|}
\hline Blood biomarkers & $\begin{array}{l}\text { Lung cancer } \\
\text { histological } \\
\text { types }\end{array}$ & Verification methods & $\begin{array}{l}\text { Sensitivity and } \\
\text { specificity of } \\
\text { biomarkers }\end{array}$ & Blood biomarkers in other disease & Reference \\
\hline KLKB1 & ADC & Western blot & - & - & [14] \\
\hline SAA & $\begin{array}{l}\text { ADC, SQLC, } \\
\text { SCLC }\end{array}$ & $\begin{array}{c}\text { Western blot, ELISA, } \\
\text { Immunohistochemistry, In vivo assay, } \\
\text { MRM }\end{array}$ & - & $\begin{array}{l}\text { Pancreatic, ovarian, renal and } \\
\text { colorectal cancer }\end{array}$ & {$[17,18,85-88]$} \\
\hline HP- $\beta$ chain & $\begin{array}{l}\text { ADC, SQLC, } \\
\text { SCLC }\end{array}$ & Western blot, ELISA & $\begin{array}{l}\text { Sensitivity : } 82.6 \% \\
\text { Specificity : } 63.2 \%\end{array}$ & $\begin{array}{l}\text { Oral, breast, liver, ovarian pancreatic } \\
\text { colorectal and bladder cancer }\end{array}$ & [20-24] \\
\hline C9 & SQLC, SCLC & $\begin{array}{l}\text { Western blot, protein arrays, Hybrid } \\
\text { AAL lectin ELISA }\end{array}$ & $\begin{array}{l}\text { Sensitivity : } 53 \% \\
\text { Specificity : } 89 \%\end{array}$ & $\begin{array}{c}\text { Cervical, gastric, colorectal and breast } \\
\text { cancer }\end{array}$ & {$[27,89-92]$} \\
\hline $\begin{array}{l}\text { IGFBP-2 and anti- } \\
\text { IGFBP-2 autoantibody }\end{array}$ & ADC, SQLC & ELISA, Immunohistochemistry & $\begin{array}{l}\text { Sensitivity : } 85.7 \% \\
\text { Specificity : } 57.5 \%\end{array}$ & $\begin{array}{l}\text { glioma, colorectal, prostate, ovarian } \\
\text { and breast cancer }\end{array}$ & [29-34] \\
\hline PRX1 & $\begin{array}{l}\text { ADC, SQLC, } \\
\text { SCLC }\end{array}$ & 2-DE screening, Western blot & - & - & [42] \\
\hline CD105 & NSCLC & ELISA & - & $\begin{array}{c}\text { Prostate, breast, colorectal and liver } \\
\text { cancers }\end{array}$ & {$[48-52,93]$} \\
\hline Pgrmc1 & ADC, SQLC & $\begin{array}{l}\text { Western blot, Immunohistochemistry, In } \\
\text { vitro assay }\end{array}$ & - & ovarian, breast cancer & {$[56,59]$} \\
\hline ProGRP & SCLC & ARCHITECT ProGRP assay & $\begin{array}{l}\text { Sensitivity : } 86.5 \% \\
\text { Specificity : } 95 \%\end{array}$ & chronic renal failure & {$[64,94]$} \\
\hline Ciz1 & $\begin{array}{l}\text { ADC, SQLC, } \\
\text { SCLC }\end{array}$ & $\begin{array}{l}\text { Western blot, Immunohistochemistry, In } \\
\text { vitro and In vivo assays }\end{array}$ & $\begin{array}{l}\text { Sensitivity : } 95 \% \\
\text { Specificity : } 74 \%\end{array}$ & - & [69] \\
\hline MMP1 & All & ELISA, Immunohistochemistry & - & $\begin{array}{l}\text { colorectal, esophageal, pancreatic, } \\
\text { gastric, breast cancer and malignant } \\
\text { melanoma }\end{array}$ & [72-77] \\
\hline uPAR & NSCLC & $\begin{array}{l}\text { Three time-resolved } \\
\text { fluoroimmunoassays (TR-FIA) }\end{array}$ & - & $\begin{array}{l}\text { Colorectal, prostate, ovarian cancer } \\
\text { and myeloma }\end{array}$ & {$[83,95-98]$} \\
\hline
\end{tabular}

Table 1: Recently reported potential lung cancer serum/plasma biomarkers.

potential N-linked glycosylation sites [26]. C9 has been identified in SQLC patients' sera by glycoproteomics approaches [27]. Fucosylated glycoproteins were enriched using the Aleuria aurantia lectin (AAL) column and were subsequently analyzed by LC-MS/MS. The C9 protein was selected as a favorable biomarker from a comparative data analysis performed using samples from healthy controls and SQLC patients. The C9 protein serum levels in SQLC patients were significantly higher than those in healthy controls and in patients with other cancer types, such as breast cancer, hepatocellular carcinoma, and stomach cancer. Western blot and densitometry analysis showed that the $\mathrm{C} 9$ protein has a specificity of $89 \%$ and a sensitivity of $53 \%$ for SQLC detection. Serum analysis using the antibody-lectin-based hybrid ELISA also showed increased fucosylation levels of C9 in SQLC patients.

\section{Insulin-like Growth Factor-Binding Protein-2 (IGFBP-2)}

Insulin-like growth factor-binding protein-2 [IGFBP-2] is a member of the insulin-like growth factor-binding protein family [IGFBPs]. The main function of IGFBP-2 is to inhibit IGF-mediated growth and development rates [28]. Increased levels of IGFBP-2 have been found in solid tumors and in blood from patients with glioma [29], colorectal [30], prostate [31], ovarian [32] and breast cancers [33]. Although increased levels of IGFBP-2 were found in the advanced stages of several cancers, fewer cases were detected in the early stages of the disease. A recent study regarding circulating anti-IGFBP-2 autoantibodies and IGFBP-2 combined markers showed increased diagnostic sensitivity and specificity for lung cancer compared to IGFBP-2 alone [34]. The serum IGFBP-2 and anti-IGFBP-2 autoantibody combined biomarkers provided a sensitivity of $85.7 \%$ and a specificity of $57.5 \%$ in the detection of lung cancer.

\section{Peroxiredoxin 1 (PRX1)}

Peroxiredoxin 1 (PRX1) and 2 belong to a family of ubiquitous multifunctional antioxidant proteins. The main function of PRX1 is to eliminate peroxides such as hydrogen peroxide $\left(\mathrm{H}_{2} \mathrm{O}_{2}\right)$ generated during metabolism [35]. PRX1 is also involved in the inhibition of oncogenes such as Ras and c-Myc [36,37]. PRX1 protein levels were found to be higher in human cancer cells and tissue samples for mesothelioma [38], breast [39,40], and head-and-neck cancers [41]. More recently, PRX1 was also identified in lung cancer patients' plasma by LC-MS/ MS-based screening technology. Plasma PRX1 levels were increased in the lung cancer group and the asbestos exposure group [42].

\section{Endoglin [CD105]}

Endoglin [CD105] is a major cell membrane glycoprotein of the vascular endothelium. It forms a complex with the signaling receptors for transforming growth factor-beta [TGF $\beta$ R1 or TGF $\beta$ R2]. It efficiently binds TGF $\beta 1$ and TGF $\beta 3[43,44]$. The main function of endoglin is to help the binding of endothelial cells to integrins and other receptors [45]. Endoglin promotes angiogenesis by the activation of endothelial cells [46]. Endoglin-overexpression has also been found in the endothelium of vessels in human solid tumors and is closely associated with a poor prognosis and the presence of metastases [47]. Levels of soluble endoglin [s-endoglin], formed by the cleavage of ectodomain of membrane receptors, were higher in patients with various types of solid tumors, including those from breast $[48,49]$, colorectal [50] and liver cancers [51] compared to normal subjects, and its levels were also correlated with the presence of metastases. A recent study comparing s-endoglin serum levels in patients with NSCLC preand post-operation found significantly decreased levels of s-endoglin post-operation [52]. Thus, s-endoglin has been confirmed as a potential monitoring and prognostic biomarker for lung cancer.

\section{Progesterone Receptor Membrane Component 1/ sigma-2 Receptor (Pgrmc1)}

Progesterone receptor membrane component 1 (Pgrmc1) is a 
cytochrome $\mathrm{b}_{5}$-related protein [53] that is induced by carcinogens $[54,55]$. Pgrmc1 levels are elevated in spontaneous ovarian, breast, and lung cancers [56]. Pgrmcl is known to localize at the endoplasmic reticulum or punctate cytoplasmic sites with epidermal growth factor receptors (EGFR) [57]. Pgrmc1 was identified as a sigma-2 receptor, which is induced in cancers [58]. Recently, Pgrmcl showed the potential to be a serum biomarker for lung cancer [59]. Pgrmc1 levels in SQLC cell lines and tissues were high compared with controls by using the immune assay and siRNA knockdown of Pgrmc1-inhibited SQLC cell proliferation and cancer cell survival. Pgrmcl is reported to be secreted protein neudesin, which binds to unknown neuron receptors and elevates AKT signaling. These findings also indicate that Pgrmcl is secreted by lung cancer cells as well as demonstrating the localization of Pgrmc1 to secretory vesicles in cancer cells. Furthermore, Pgrmc1 levels in the plasma and in the exosome fractions of plasma were significantly increased in lung cancer groups (ADC, SQLC, LCC).

\section{Pro-gastrin-releasing Peptide (proGRP)}

Pro-gastrin-releasing peptide (proGRP, residue 31-98) is a more stable biochemical precursor of gastrin-releasing peptide [GRP] that is specifically produced by the neuroendocrine origin of SCLC cells [60]. Circulating proGRP is suggested to serve as a potential diagnostic marker for SCLC [61-63]. In a recent report, plasma proGRP levels were increased in SCLC patients relative to the levels in patients with other types of lung cancer [specificity of 95\%]. Its levels also gradually increased with the progression of the disease [64].

\section{p21(Cip1)-interacting zinc finger protein (Ciz1)}

Ciz1 is a nuclear matrix protein, and its main function is to promote the initiation of mammalian DNA replication [65]. Nuclear matrix proteins offer several advantages as biomarkers. They are localized in the nucleus, which is the heart of dysregulated conditions during carcinogenesis formation. Therefore, nuclear matrix proteins such as NMP22, BCLA4, PC1, and NM179 were suggested as tumor markers for bladder [66], cervix [67], and prostate cancer [68]. Recently, B-variant Ciz1 (24 nucleotides from the 3' end of exon 14 are excluded, leading to in-frame deletion of eight amino acids 'VEEELCKQ') protein levels were significantly increased in the plasma of early stage lung cancer patients compared with the plasma from normal controls and patients with other respiratory diseases. The growth of tumor cells was significantly reduced when B-variant Cizl was depleted using RNAi in vitro and in vivo [69]. B-variant Cizl is a potential diagnostic lung cancer-specific marker. The sensitivity and specificity of Cizl for stage I NSCLC were $95 \%$ and $74 \%$, respectively.

\section{Matrix Metalloproteinase-1 [MMP-1]}

MMP-1 is a collagenase that cleaves collagen types I, II, III, VII and $\mathrm{X}$ at one site in the helical structure [70]. It is well known to be overexpressed in various cancer cells during the invasion and metastasis phases [71]. The up-regulated expression of MMP-1 has been detected in colorectal [72], esophageal [73], pancreatic [74], gastric [75], breast cancer [76] and malignant melanoma [74]. A recent study that measured MMP-1 levels in plasma and tissue samples from lung cancer patients showed that higher plasma levels of MMP-1 and tumor progression (i.e., tumor size, staging and lymphatic invasion) were associated with a lower patient survival rate [77].

\section{Urokinase Plasminogen Activator Receptor (uPAR)}

uPAR is a glycosylphosphatidylinositol (GPI)-anchored glycoprotein and cell surface receptor specific to the urokinase
Plasminogen Activator ( $\mathrm{UPA}$ ) and is a promoter of plasmin activation. uPAR consists of three homologous domains, denoted by I, II and III [78]. The uPA-catalyzed cleavage of uPAR is a negative feedback loop in which uPA cleaves uPAR between domains I and II, releasing I (uPAR(I)) and leaving the cleaved form uPAR(II-III) attached to the cell surface $[79,80]$. Increased levels of cleaved uPAR were found in a blood sample from an NSCLC patient [81,82]. A recent analysis of serum and plasma levels in pre-operative NSCLC patients correlated with higher levels of cleaved uPAR and lower survival rates [83].

\section{Conclusions}

The recent advances developed in proteomics technology specifically improved techniques for the identification, detection, and verification of biomarkers and have thus improved our understanding of lung cancer. Earlier diagnosis of lung cancer is urgently needed to decrease the lung cancer mortality rate. A noninvasive technique that integrates an understanding of lung cancer biomarkers and identifies lung cancer patients from hemo-analysis would be a better alternative to the current diagnostic methods. From our experience studying lung cancer biomarkers, we have found that many protein/peptide biomarkers discovered in the serum and/or plasma seem to overlap with other diseases, especially other cancers and inflammatory diseases. Thus, the discovery of more lung tissue-specific biomarkers is needed, starting with tissue-specific genes/proteins and the related proteins in lung tissues and lung cancers.

The best method to verify a lung cancer diagnosis would be one that involves a multiple biomarker approach rather than a single biomarker approach. The sensitivity and specificity of anti-IGFBP-2 autoantibodies in lung cancer patients' sera were $73.2 \%$ and $60.6 \%$, respectively. However, combination of IGFBP-2 and anti-IGFBP-2 autoantibody increased the sensitivity and specificity $(85.7 \%$ and 57.5\%) for diagnosing lung cancer [34]. Also, lung cancer patients with lymph node metastasis had higher level of serum vascular endothelial growth factor (VEGF)-C, MMP-9 and VEGF than those without metastasis [84]. Serum VEGF-C reached a sensitivity of $85 \%$ and specificity of $68 \%$, while MMP-9 was $63 \%$ sensitivity and $75 \%$ specificity. VEGF reached a sensitivity of $80 \%$ and specificity of $59 \%$. However, combination of three markers had higher sensitivity and specificity $(83 \%$ and $76 \%)$ than single biomarker approach. Although some biomarkers show high sensitivity and specificity, it should be noted that small-scale verification in retrospectively selected samples from one institution may not represent a general test with the samples prospectively collected from multiple institutions. With plenty of lung cancer biomarkers mentioned above and many more that are published, now is the time to extensively validate the markers in large-scale clinical samples and to assess their effectiveness in various combinations to develop an optimized multi-marker approach. Therefore, the combination of multiple biomarkers that best distinguishes cancer samples from controls should be utilized in the development of cancer detection technology for clinical applications.

\section{Acknowledgements}

This work was supported by the Post 21C Frontier Project (No. M3C5A105334) from the Korean Ministry of Education, Science and Technology (MEST), the National Research Foundation of Korea (NRF) grant (2012036669).

\section{References}

1. Granville CA, Dennis PA (2005) An overview of lung cancer genomics and proteomics. Am J Respir Cell Mol Biol 32: 169-176.

2. Indovina P, Marcelli E, Pentimalli F, Tanganelli P, Tarro G, et al. (2013) Mass spectrometry-based proteomics: The road to lung cancer biomarker discovery. Mass Spectrom Rev 32: 129-142. 
3. Mulshine $\mathrm{JL}$ (2005) Current issues in lung cancer screening. Oncology (Williston Park) 19: 1724-1730.

4. Henschke Cl, McCauley DI, Yankelevitz DF, Naidich DP, McGuinness G, et al. (1999) Early Lung Cancer Action Project: overall design and findings from baseline screening. Lancet 354: 99-105.

5. Kikuchi T, Carbone DP (2007) Proteomics analysis in lung cancer: challenges and opportunities. Respirology 12: 22-28.

6. Cho WC (2007) Potentially useful biomarkers for the diagnosis, treatment and prognosis of lung cancer. Biomed Pharmacother 61: 515-519.

7. Okada M, Nishio W, Sakamoto T, Uchino K, Yuki T, et al. (2004) Prognostic significance of perioperative serum carcinoembryonic antigen in non-smal cell lung cancer: analysis of 1,000 consecutive resections for clinical stage I disease. Ann Thorac Surg 78: 216-221.

8. Schneider J (2006) Tumor markers in detection of lung cancer. Adv Clin Chem 42: $1-41$

9. Kulpa J, Wojcik E, Reinfuss M, Kolodziejski L (2002) Carcinoembryonic antigen, squamous cell carcinoma antigen, CYFRA 21-1, and neuron-specific enolase in squamous cell lung cancer patients. Clin Chem 48: 1931-1937.

10. Greenberg AK, Lee MS (2007) Biomarkers for lung cancer: clinical uses. Curr Opin Pulm Med 13: 249-255.

11. Ferrigno D, Buccheri G, Giordano C (2003) Neuron-specific enolase is an effective tumour marker in non-small cell lung cancer (NSCLC). Lung Cancer 41: 311-320.

12. Xu M, Zhu M, Du Y, Yan B, Wang Q, et al. (2013) Serum C-reactive protein and risk of lung cancer: a case-control study. Med Oncol 30: 319.

13. Chung DW, Fujikawa K, McMullen BA, Davie EW (1986) Human plasma prekallikrein, a zymogen to a serine protease that contains four tandem repeats. Biochemistry 25: 2410-2417.

14. Heo SH, Lee SJ, Ryoo HM, Park JY, Cho JY (2007) Identification of putative serum glycoprotein biomarkers for human lung adenocarcinoma by multilectin affinity chromatography and LC-MS/MS. Proteomics 7: 4292-4302.

15. Uhlar CM, Whitehead AS (1999) Serum amyloid A, the major vertebrate acutephase reactant. Eur J Biochem 265: 501-523.

16. Jensen LE, Whitehead AS (1998) Regulation of serum amyloid A protein expression during the acute-phase response. Biochem J 334: 489-503.

17. Sung HJ, Ahn JM, Yoon YH, Rhim TY, Park CS, et al. (2011) Identification and validation of SAA as a potential lung cancer biomarker and its involvement in metastatic pathogenesis of lung cancer. J Proteome Res 10: 1383-1395.

18. Sung HJ, Jeon SA, Ahn JM, Seul KJ, Kim JY, et al. (2012) Large-scale isotypespecific quantification of Serum amyloid $A 1 / 2$ by multiple reaction monitoring in crude sera. J Proteomics 75: 2170-2180.

19. Kristiansen M, Graversen JH, Jacobsen C, Sonne O, Hoffman HJ, et al. (2001) Identification of the haemoglobin scavenger receptor. Nature 409: 198-201.

20. Hamrita B, Chahed K, Trimeche M, Guillier CL, Hammann P, et al. (2009) Proteomics-based identification of alpha1-antitrypsin and haptoglobin precursors as novel serum markers in infiltrating ductal breast carcinomas. Clin Chim Acta 404: 111-118.

21. Zhao C, Annamalai L, Guo C, Kothandaraman N, Koh SC, et al. (2007) Circulating haptoglobin is an independent prognostic factor in the sera of patients with epithelial ovarian cancer. Neoplasia 9: 1-7.

22. Firpo MA, Gay DZ, Granger SR, Scaife CL, DiSario JA, et al. (2009) Improved diagnosis of pancreatic adenocarcinoma using haptoglobin and serum amyloid A in a panel screen. World J Surg 33: 716-722.

23. Benkmann HG, Hanssen HP, Ovenbeck R, Goedde HW (1987) Distribution of alpha-1-antitrypsin and haptoglobin phenotypes in bladder cancer patients. Hum Hered 37: 290-293.

24. Kang SM, Sung HJ, Ahn JM, Park JY, Lee SY, et al. (2011) The Haptoglobin $\beta$ chain as a supportive biomarker for human lung cancers. Mol Biosyst 7: 11671175 .

25. Liszewski MK, Farries TC, Lublin DM, Rooney IA, Atkinson JP (1996) Contro of the complement system. Adv Immunol 61: 201-283.

26. Chen R, Jiang X, Sun D, Han G, Wang F, et al. (2009) Glycoproteomics analysis of human liver tissue by combination of multiple enzyme digestion and hydrazide chemistry. J Proteome Res 8: 651-661.
27. Narayanasamy A, Ahn JM, Sung HJ, Kong DH, Ha KS, et al. (2011) Fucosylated glycoproteomic approach to identify a complement component 9 associated with squamous cell lung cancer (SQLC). J Proteomics 74: 2948-2958.

28. Zhou J, Li W, Kamei H, Duan C (2008) Duplication of the IGFBP-2 gene in teleost fish: protein structure and functionality conservation and gene expression divergence. PLoS One 3: e3926.

29. Lin Y, Jiang T, Zhou K, Xu L, Chen B, et al. (2009) Plasma IGFBP-2 levels predict clinical outcomes of patients with high-grade gliomas. Neuro Oncol 11 468-476.

30. Miraki-Moud F, Jenkins PJ, Fairclough PD, Jordan S, Bustin SA, et al. (2001) Increased levels of insulin-like growth factor binding protein-2 in sera and tumours from patients with colonic neoplasia with and without acromegaly. Clin Endocrinol (Oxf) 54: 499-508.

31. Shariat SF, Lamb DJ, Kattan MW, Nguyen C, Kim J, et al. (2002) Association of preoperative plasma levels of insulin-like growth factor I and insulin-like growth factor binding proteins- 2 and -3 with prostate cancer invasion, progression, and metastasis. J Clin Oncol 20: 833-841.

32. Wang $H$, Rosen DG, Wang $H$, Fuller GN, Zhang W, et al. (2006) Insulin-like growth factor-binding protein 2 and 5 are differentially regulated in ovarian cancer of different histologic types. Mod Pathol 19: 1149-1156.

33. Busund LT, Richardsen E, Busund R, Ukkonen T, Bjørnsen T, et al. (2005) Significant expression of IGFBP2 in breast cancer compared with benign lesions. J Clin Pathol 58: 361-366.

34. Zhang Y, Ying X, Han S, Wang J, Zhou X, et al. (2013) Autoantibodies against insulin-like growth factorâ€'binding protein-2 as a serological biomarker in the diagnosis of lung cancer. Int J Oncol 42: 93-100.

35. Rhee SG, Kang SW, Chang TS, Jeong W, Kim K (2001) Peroxiredoxin, a nove family of peroxidases. IUBMB Life 52 : 35-41.

36. Neumann CA, Fang Q (2007) Are peroxiredoxins tumor suppressors? Curr Opin Pharmacol 7: 375-380.

37. Graves JA, Metukuri M, Scott D, Rothermund K, Prochownik EV (2009) Regulation of reactive oxygen species homeostasis by peroxiredoxins and c-Myc. J Biol Chem 284: 6520-6529.

38. Kinnula VL, Lehtonen S, Sormunen R, Kaarteenaho-Wiik R, Kang SW, et al. (2002) Overexpression of peroxiredoxins I, II, III, V, and VI in malignant mesothelioma. J Pathol 196: 316-323

39. Noh DY, Ahn SJ, Lee RA, Kim SW, Park IA, et al. (2001) Overexpression of peroxiredoxin in human breast cancer. Anticancer Res 21: 2085-2090.

40. Cha MK, Suh KH, Kim IH (2009) Overexpression of peroxiredoxin I and thioredoxin1 in human breast carcinoma. J Exp Clin Cancer Res 28: 93.

41. Demasi AP, Furuse C, Altemani A, Junqueira JL, Oliveira PR, et al. (2009) Peroxiredoxin I is overexpressed in oncocytic lesions of salivary glands. J Oral Pathol Med 38: 514-517.

42. Rostila A, Puustinen A, Toljamo T, Vuopala K, Lindström I, et al. (2012) Peroxiredoxins and tropomyosins as plasma biomarkers for lung cancer and asbestos exposure. Lung Cancer 77: 450-459.

43. Meng Q, Lux A, Holloschi A, Li J, Hughes JM, et al. (2006) Identification of Tctex2beta, a novel dynein light chain family member that interacts with different transforming growth factor-beta receptors. J Biol Chem 281: 37069 37080 .

44. Lee NY, Blobe GC (2007) The interaction of endoglin with beta-arrestin2 regulates transforming growth factor-beta-mediated ERK activation and migration in endothelial cells. J Biol Chem 282: 21507-21517.

45. Gougos A, Letarte M (1990) Primary structure of endoglin, an RGD-containing glycoprotein of human endothelial cells. J Biol Chem 265: 8361-8364

46. Lebrin F, Goumans MJ, Jonker L, Carvalho RL, Valdimarsdottir G, et al. (2004) Endoglin promotes endothelial cell proliferation and TGF-beta/ALK1 signal transduction. EMBO J 23: 4018-4028.

47. Dallas NA, Samuel S, Xia L, Fan F, Gray MJ, et al. (2008) Endoglin (CD105): marker of tumor vasculature and potential target for therapy. Clin Cancer Res 14: 1931-1937.

48. Li C, Guo B, Wilson PB, Stewart A, Byrne G, et al. (2000) Plasma levels of soluble CD105 correlate with metastasis in patients with breast cancer. Int $J$ Cancer 89: 122-126. 
49. Takahashi N, Kawanishi-Tabata R, Haba A, Tabata M, Haruta Y, et al. (2001) Association of serum endoglin with metastasis in patients with colorectal, breast, and other solid tumors, and suppressive effect of chemotherapy on the serum endoglin. Clin Cancer Res 7: 524-532.

50. Myśliwiec P, Pawlak K, Kukliński A, Kedra B (2009) Combined perioperative plasma endoglin and VEGF--a assessment in colorectal cancer patients. Folia Histochem Cytobiol 47: 231-236.

51. Yagmur E, Rizk M, Stanzel S, Hellerbrand C, Lammert F, et al. (2007) Elevation of endoglin (CD105) concentrations in serum of patients with liver cirrhosis and carcinoma. Eur J Gastroenterol Hepatol 19: 755-761.

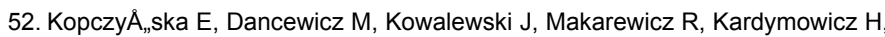
et al. (2012) Influence of surgical resection on plasma endoglin (CD105) level in nonâ€'small cell lung cancer patients. Exp Oncol 34: 53-56.

53. Mifsud W, Bateman A (2002) Membrane-bound progesterone receptors contain a cytochrome b5-like ligand-binding domain. Genome Biol 3: RESEARCH0068.

54. Selmin O, Lucier GW, Clark GC, Tritscher AM, Vanden Heuvel JP, et al. (1996) Isolation and characterization of a novel gene induced by 2,3,7,8-tetrachlorodibenzo-p-dioxin in rat liver. Carcinogenesis 17: 2609-2615.

55. Nie AY, McMillian M, Parker JB, Leone A, Bryant S, et al. (2006) Predictive toxicogenomics approaches reveal underlying molecular mechanisms of nongenotoxic carcinogenicity. Mol Carcinog 45: 914-933.

56. Min L, Strushkevich NV, Harnastai IN, Iwamoto H, Gilep AA, et al. (2005) Molecular identification of adrenal inner zone antigen as a heme-binding protein. FEBS J 272: 5832-5843.

57. Ahmed IS, Rohe HJ, Twist KE, Craven RJ (2010) Pgrmc1 (progesterone receptor membrane component 1) associates with epidermal growth factor receptor and regulates erlotinib sensitivity. J Biol Chem 285: 24775-24782.

58. Xu J, Zeng C, Chu W, Pan F, Rothfuss JM, et al. (2011) Identification of the PGRMC1 protein complex as the putative sigma-2 receptor binding site. Nat Commun 2: 380

59. Mir SU, Ahmed IS, Arnold S, Craven RJ (2012) Elevated progesterone receptor membrane component 1/sigma-2 receptor levels in lung tumors and plasma from lung cancer patients. Int J Cancer 131: E1-9.

60. Miyake Y, Kodama T, Yamaguchi K (1994) Pro-gastrin-releasing peptide (3198 ) is a specific tumor marker in patients with small cell lung carcinoma. Cancer Res 54: 2136-2140.

61. Takada M, Kusunoki Y, Masuda N, Matui K, Yana T, et al. (1996) Pro-gastrinreleasing peptide (31-98) as a tumour marker of small-cell lung cancer: comparative evaluation with neuron-specific enolase. $\mathrm{Br} J$ Cancer 73: 12271232.

62. Molina R, Filella X, Augé JM (2004) ProGRP: a new biomarker for small cell lung cancer. Clin Biochem 37: 505-511.

63. Stieber P, Dienemann H, Schalhorn A, Schmitt UM, Reinmiedl J, et al. (1999) Pro-gastrin-releasing peptide (ProGRP)--a useful marker in small cell lung carcinomas. Anticancer Res 19: 2673-2678.

64. Kim HR, Oh IJ, Shin MG, Park JS, Choi HJ, et al. (2011) Plasma proGRP concentration is sensitive and specific for discriminating small cell lung cancer from nonmalignant conditions or non-small cell lung cancer. J Korean Med Sci 26: $625-630$

65. Coverley D, Marr J, Ainscough J (2005) Ciz1 promotes mammalian DNA replication. J Cell Sci 118: 101-112.

66. Van Le TS, Myers J, Konety BR, Barder T, Getzenberg RH (2004) Functional characterization of the bladder cancer marker, BLCA-4. Clin Cancer Res 10: 1384-1391.

67. Keesee SK, Meyer JL, Hutchinson ML, Cibas ES, Sheets EE, et al. (1999) Preclinical feasibility study of NMP179, a nuclear matrix protein marker for cervical dysplasia. Acta Cytol 43: 1015-1022.

68. Subong EN, Shue MJ, Epstein JI, Briggman JV, Chan PK, et al. (1999) Monoclonal antibody to prostate cancer nuclear matrix protein (PRO:4-216) recognizes nucleophosmin/B23. Prostate 39: 298-304.

69. Higgins G, Roper KM, Watson IJ, Blackhall FH, Rom WN, et al. (2012) Variant Ciz1 is a circulating biomarker for early-stage lung cancer. Proc Natl Acad Sci U S A 109: E3128-3135.

70. Desrochers PE, Jeffrey JJ, Weiss SJ (1991) Interstitial collagenase (matrix metalloproteinase-1) expresses serpinase activity. J Clin Invest 87: 2258-2265.
71. Brinckerhoff CE, Rutter JL, Benbow U (2000) Interstitial collagenases as markers of tumor progression. Clin Cancer Res 6: 4823-4830.

72. Murray GI, Duncan ME, O'Neil P, Melvin WT, Fothergill JE (1996) Matrix metalloproteinase- 1 is associated with poor prognosis in colorectal cancer. Nat Med 2: 461-462.

73. Murray GI, Duncan ME, O'Neil P, McKay JA, Melvin WT, et al. (1998) Matrix metalloproteinase- 1 is associated with poor prognosis in oesophageal cancer J Pathol 185: 256-261.

74. Airola K, Karonen T, Vaalamo M, Lehti K, Lohi J, et al. (1999) Expression of collagenases- 1 and -3 and their inhibitors TIMP- 1 and -3 correlates with the level of invasion in malignant melanomas. $\mathrm{Br} \mathrm{J}$ Cancer 80: 733-743.

75. Inoue T, Yashiro M, Nishimura S, Maeda K, Sawada T, et al. (1999) Matrix metalloproteinase-1 expression is a prognostic factor for patients with advanced gastric cancer. Int J Mol Med 4: 73-77.

76. Poola I, DeWitty RL, Marshalleck JJ, Bhatnagar R, Abraham J, et al. (2005) Identification of MMP-1 as a putative breast cancer predictive marker by globa gene expression analysis. Nat Med 11: 481-483.

77. Li M, Xiao T, Zhang Y, Feng L, Lin D, et al. (2010) Prognostic significance of matrix metalloproteinase-1 levels in peripheral plasma and tumour tissues of lung cancer patients. Lung Cancer 69: 341-347.

78. Behrendt N, Ronne E, Dano K (1996) Domain interplay in the urokinase receptor. Requirement for the third domain in high affinity ligand binding and demonstration of ligand contact sites in distinct receptor domains. J Biol Chem 271: 22885-22894.

79. Høyer-Hansen G, Behrendt N, Ploug M, Danø K, Preissner KT (1997) The intact urokinase receptor is required for efficient vitronectin binding: receptor cleavage prevents ligand interaction. FEBS Lett 420: 79-85.

80. Høyer-Hansen G, Ploug M, Behrendt N, Rønne E, Danø K (1997) Cell-surface acceleration of urokinase-catalyzed receptor cleavage. Eur J Biochem 243: 21 26.

81. Cobos E, Jumper C, Lox C (2003) Pretreatment determination of the serum urokinase plasminogen activator and its soluble receptor in advanced smallcell lung cancer or non-small-cell lung cancer. Clin Appl Thromb Hemost 9 : 241-246.

82. Pappot H, Høyer-Hansen G, Rønne E, Hansen HH, Brünner N, et al. (1997) Elevated plasma levels of urokinase plasminogen activator receptor in nonsmall cell lung cancer patients. Eur J Cancer 33: 867-872.

83. Almasi CE, Høyer-Hansen G, Christensen IJ, Pappot H (2009) Prognostic significance of urokinase plasminogen activator receptor and its cleaved forms in blood from patients with non-small cell lung cancer. APMIS 117: 755-761.

84. Tamura M, Oda M, Matsumoto I, Tsunezuka Y, Kawakami K, et al. (2004) The combination assay with circulating vascular endothelial growth facto (VEGF)-C, matrix metalloproteinase-9, and VEGF for diagnosing lymph node metastasis in patients with non-small cell lung cancer. Ann Surg Oncol 11: 928-933.

85. Yokoi K, Shih LC, Kobayashi R, Koomen J, Hawke D, et al. (2005) Serum amyloid $\mathrm{A}$ as a tumor marker in sera of nude mice with orthotopic human pancreatic cancer and in plasma of patients with pancreatic cancer. Int J Oncol 27: 1361-1369.

86. Edgell T, Martin-Roussety G, Barker G, Autelitano DJ, Allen D, et al. (2010) Phase II biomarker trial of a multimarker diagnostic for ovarian cancer. J Cancer Res Clin Oncol 136: 1079-1088.

87. Nobata H, Suga N, Itoh A, Miura N, Kitagawa W, et al. (2012) Systemic $\mathrm{AA}$ amyloidosis in a patient with lung metastasis from renal cell carcinoma. Amyloid 19: 197-200

88. Byström P, Berglund A, Nygren P, Wernroth L, Johansson B, et al. (2012) Evaluation of predictive markers for patients with advanced colorectal cancer. Acta Oncol 51: 849-859.

89. Onizuka K, Migita S, Yamada H, Uwada O, Umemura Y, et al. (1994) [Studies on serum protein fractions of patients with uterine cervical cancer undergoing radiotherapy: relationship between changes in serum protein fractions and prognosis]. Nihon Igaku Hoshasen Gakkai Zasshi 54: 1007-1017.

90. Chong PK, Lee H, Loh MC, Choong LY, Lin Q, et al. (2010) Upregulation of plasma C9 protein in gastric cancer patients. Proteomics 10: 3210-3221.

91. Murakoshi Y, Honda K, Sasazuki S, Ono M, Negishi A, et al. (2011) Plasma 
biomarker discovery and validation for colorectal cancer by quantitative shotgun mass spectrometry and protein microarray. Cancer Sci 102: 630-638.

92. Hyung SW, Lee MY, Yu JH, Shin B, Jung HJ, et al. (2011) A serum protein profile predictive of the resistance to neoadjuvant chemotherapy in advanced breast cancers. Mol Cell Proteomics 10: M111.

93. Svatek RS, Karam JA, Roehrborn CG, Karakiewicz PI, Slawin KM, et al. (2008) Preoperative plasma endoglin levels predict biochemical progression after radical prostatectomy. Clin Cancer Res 14: 3362-3366.

94. Nomura F, Koyama A, Ishijima M, Takano S, Narita M, et al. (1998) Serum levels of five tumor markers for lung cancer in patients with chronic renal failure. Oncol Rep 5: 389-392.

95. Lomholt AF, Christensen IJ, Høyer-Hansen G, Nielsen HJ (2010) Prognostic value of intact and cleaved forms of the urokinase plasminogen activator receptor in a retrospective study of 518 colorectal cancer patients. Acta Oncol 49: 805-811.

96. Shariat SF, Roehrborn CG, McConnell JD, Park S, Alam N, et al. (2007) Association of the circulating levels of the urokinase system of plasminogen activation with the presence of prostate cancer and invasion, progression, and metastasis. J Clin Oncol 25: 349-355.

97. Begum FD, Høgdall CK, Kjaer SK, Christensen L, Blaakaer J, et al. (2004) The prognostic value of plasma soluble urokinase plasminogen activator receptor (suPAR) levels in stage III ovarian cancer patients. Anticancer Res 24: 1981 1985.

98. Rigolin GM, Tieghi A, Ciccone M, Bragotti LZ, Cavazzini F, et al. (2003) Soluble urokinase-type plasminogen activator receptor (suPAR) as an independent factor predicting worse prognosis and extra-bone marrow involvement in multiple myeloma patients. Br J Haematol 120: 953-959.
This article was originally published in a special issue, Protein \& Prognostic Biomarkers handled by Editor(s). Dr. David Zhang, Fudan University, USA; Dr. Wellington Pham, Vanderbilt University, USA; Jin-ichi Inokuchi, Tohoku Pharmaceutical University, Japan 